\title{
Prevalence of depression among students of medical college in UPUMS, Saifai - A cross- sectional study
}

\author{
Deepali Raj Singh', Sandip Kumar,", P. K. Bajpai ${ }^{3}$, P. K. Jain ${ }^{4}$, Mahima ${ }^{5}$ \\ 1,5Postgraduate Student, ${ }^{2}$ Professor, ${ }^{3}$ Lecturer, ${ }^{4}$ Professor and Head, Dept. of Community Medicine, Uttar Pradesh University of Medical \\ Sciences, Saifai, Etawah, Uttar Pradesh, India \\ *Corresponding Author: Sandip Kumar \\ Email: drsandiprims@yahoo.co.in
}

\begin{abstract}
Introduction and Objectives: Depression is a common mental disorder which is often unrecognised. Medical education is associated with various pressures and stresses which can lead to depression and represents a neglected public health problem in India. Consequently prevalence of depression is higher in medical students as compared to the general population.

Objectives:

1. To assess the prevalence of depression among medical students.

2. To find out socio-demographic correlates of depression.

Materials and Methods: This is a cross-sectional study among medical students from 1st year to final year of UPUMS, Saifai. Sociodemographic details were collected using pre-tested, semi-structured questionnaire and Beck depression inventory scale was used to assess the depression level. Data were analyzed using SPSS ver.23 software and appropriate statistical tests were applied. Level of significance was set at a $\mathrm{p}<0.05$.

Results: Of the 300 medical students participated in the study, 123(41\%) were males and $127(42.33 \%)$ were females. The overall prevalence of depression was found to be 23 percent. This is more common in females i.e. (27\%) than males (20\%) other factors, including gender, loss of loved in the family, financial problem, and education of parents were not found to have any significant association with prevalence of depression in the study. It was also observed that students were reluctant to seek help for depressive symptoms.

Conclusion: Depression is quiet common among medical students, majority of the time it is unrecognised \& it has a long term consequences on the overall development of the student.
\end{abstract}

Keywords: Depression, Medical students, Socio demographic correlates, BDI, MBBS.

\section{Introduction}

According to WHO, depression is defined as a common mental disorder characterised by sadness, loss of interest, feelings of guilt or low self-worth, disturbed sleep or appetite, feeling of tiredness and poor concentration. ${ }^{1}$ Depression is highly common and it would be the secondmost prevalent condition worldwide by $2020,{ }^{2}$ which is often unrecognised.

General people expect medical students to be better than their peers in other walks of life when it comes to health, and it hold true up to certain extent as far as medical illnesses are concerned. ${ }^{4}$ When we look at stress and anxiety, however, this particular population seems to be on the receiving end of the spectrum.

Medical students are exposed to significant psychological and academic stressors like burden of vast academic course with an obligation to succeed, emotional, social, physical and family problems, and an uncertain future. ${ }^{5}$ On Comparing with the general population, physicians and medical students already suffer with significantly greater frequency of stress and anxietyassociated mental disorders. ${ }^{6,7}$ Multiple studies have been reported this high-stress levels in medical students, which. ${ }^{8-}$ 13 which can contribute to substance abuse, broken relationship, suicide and attrition from the profession on personal level, and on professional level, studies suggest that student distress contribute to cynicism and may affect relationship with faculty, care of patients, and ultimately the culture of the medical profession. ${ }^{14}$

\section{Methodology \\ Study Design: Cross-sectional Study Saifai, Etawah Sciences, Saifai, Etawah. didn't give consent for the study. students were taken for the purpose of study \\ $\mathrm{N}=4 \mathrm{PQ} / \mathrm{L}^{2}$ \\ Where $\mathrm{P}=$ prevalence \\ $\mathrm{Q}=100-\mathrm{P}$ \\ $\mathrm{L}=$ allowable error, \\ $\mathrm{N}=(4 \times 21.5 \times 78.5) /(5 \times 5)=270.04=300$ \\ Method of Collection of Data}

Study Period: 1st August 2017- 31st January 2018

Study Area: Uttar Pradesh University of Medical sciences,

Study Subjects: Medical Students (MBBS) from first year to final year of Uttar Pradesh University of Medical

Inclusion Criteria: Inclusion criteria were medical students of Uttar Pradesh University of Medical Sciences, Saifai.

Exclusion Criteria: Exclusion criteria were students who

Sample Size: By considering prevalence of $21.5 \%{ }^{15}$ and allowable error 5\% the sample size is calculated and 300

A total of 300 medical students from $1^{\text {st }}$ year to final year, 75 students from each year were taken. Sociodemographic details were collected and beck depression inventory scale $\mathrm{BDI}^{16}$ a psychometrically sound measure for screening depression among adolescents was used to assess the depression level after taking verbal consent from students. Data were collected after explaining them about 
the study and each question. Privacy of the participants was maintained throughout the study and we have taken care that participant's identity is not disclosed at any point during the study.

\section{Statistical Analysis}

Data was entered using Microsoft Excel 2007 and was analyzed using statistical package for the social sciences software version 23 and appropriate statistical tests were applied. Level of significance was kept at a $\mathrm{p}<0.05$.

\section{Results}

A total of 300 study subjects participated in the study $173(57.6 \%)$ were males and $127(42.3 \%)$ females. The age of the study population ranged from 19-30 yrs. Mean age (in yrs) $22.6 \pm 4.2$. The overall prevalence of depression among medical students was found to be $23 \%$ and among those with depression, majority $(21.3 \%)$ had mild and moderate degree of depression while the prevalence of severe depression was 1.9 percent respectively. (Table 1)

The present study showed that the prevalence of depression was (27\%) among females and (20\%) among males but the correlation between depression and sex was not statistically significant (P-value >0.05). There was statistically significant association between other sociodemographic factors like (age, education of father) (Table $3)$.

The prevalence of depression was found 2.08 times more in students with increasing age and it was found to be statistically significant $(\chi 2=5.6, \mathrm{df}=1$, Odds $=2.08, \mathrm{p}<0.05)$.

We also found highly significant association with the other factors like chronic illness, abused by parents, and family history of depression. (Table 3)

Table: 1 Grading of depression among study subjects

\begin{tabular}{|l|c|}
\hline $\begin{array}{l}\text { Grading of the } \\
\text { subjects }\end{array}$ & Frequency \\
\hline No Depression & $180(60 \%)$ \\
\hline Normal & $5016.6 \%)$ \\
\hline Mild mood disturbance & \\
\hline Depression & $28(9.33 \%)$ \\
\hline Borderline & $36(12 \%)$ \\
\hline Moderate & $4(1.33 \%)$ \\
\hline Severe & $2(0.6 \%)$ \\
\hline Extreme & $300(100 \%)$ \\
\hline Total &
\end{tabular}

Table 2: Socio-demographic profile of the study subjects

\begin{tabular}{|c|c|c|c|c|}
\hline $\begin{array}{c}\begin{array}{c}\text { Socio-demographic } \\
\text { characteristics }\end{array} \\
\end{array}$ & \multicolumn{2}{|c|}{ Male } & \multicolumn{2}{|c|}{ Female } \\
\hline Age & No. & $\%$ & No. & $\%$ \\
\hline $19-24 \mathrm{yr}$ & 124 & $72 \%$ & 115 & $90 \%$ \\
\hline \multirow[t]{2}{*}{$25-30 \mathrm{yr}$} & 49 & $28 \%$ & 12 & $9.4 \%$ \\
\hline & 173 & $100 \%$ & 127 & $100 \%$ \\
\hline \multicolumn{5}{|l|}{ Religion } \\
\hline Hindu & 143 & $83 \%$ & 109 & $85.8 \%$ \\
\hline Muslim & 24 & $13.8 \%$ & 17 & $13.3 \%$ \\
\hline \multirow[t]{2}{*}{ Others } & 6 & $3.4 \%$ & 1 & $0.7 \%$ \\
\hline & 173 & $100 \%$ & 127 & $100 \%$ \\
\hline \multicolumn{5}{|l|}{ Hindi/English medium } \\
\hline Hindi & 87 & $57 \%$ & 30 & $23.6 \%$ \\
\hline \multirow[t]{2}{*}{ English } & 86 & $49.7 \%$ & 127 & $76.4 \%$ \\
\hline & 173 & $100 \%$ & 157 & $100 \%$ \\
\hline \multicolumn{5}{|l|}{ Family Type } \\
\hline Nuclear & 104 & $60 \%$ & 96 & $76 \%$ \\
\hline Joint & 53 & $31 \%$ & 16 & $12.6 \%$ \\
\hline \multirow[t]{2}{*}{ Three- generation } & 16 & $9.2 \%$ & 15 & $12 \%$ \\
\hline & 173 & $100 \%$ & 127 & $100 \%$ \\
\hline \multicolumn{5}{|l|}{ Orphan hood } \\
\hline Not orphan & 165 & $95.4 \%$ & 120 & $94.5 \%$ \\
\hline Paternal orphan & 8 & $4.6 \%$ & 5 & $3.9 \%$ \\
\hline \multirow[t]{2}{*}{ Maternal orphan } & 0 & $0 \%$ & 2 & $1.6 \%$ \\
\hline & 173 & $100 \%$ & 127 & $100 \%$ \\
\hline
\end{tabular}


Table 3: Association of socio-demographic characteristics with depression

\begin{tabular}{|c|c|c|c|c|c|}
\hline Age & Depression (\%) & No Depression (\%) & & \multirow{4}{*}{$\begin{array}{c}\text { Chi-sq }=5.64 \\
\mathrm{df}=1 \\
\text { Odds ratio=2.08 } \\
\text { CI }=1.1-3.8\end{array}$} & \multirow{4}{*}{$\begin{array}{r}\text { P-value } \\
<0.05\end{array}$} \\
\hline$* 19-24 \mathrm{yr}$ & $48(20 \%)$ & $191(80 \%)$ & $239(100 \%)$ & & \\
\hline \multirow[t]{2}{*}{$25-30 \mathrm{yr}$} & $21(34.4 \%)$ & $40(66 \%)$ & $61(100 \%)$ & & \\
\hline & 69 & 231 & & & \\
\hline \multicolumn{4}{|l|}{ Gender } & \multirow{4}{*}{$\begin{array}{c}\text { Chi-sq }=1.7 \\
\mathrm{df}=1 \\
\text { Odds ratio=1.4 } \\
\text { CI }=0.8-2.4\end{array}$} & \multirow{4}{*}{$>0.05$} \\
\hline Male & $35(20 \%)$ & $138(80 \%)$ & $173(100 \%)$ & & \\
\hline \multirow[t]{2}{*}{ Female } & $34(27 \%)$ & $93(73.2 \%)$ & $127(100 \%)$ & & \\
\hline & 69 & 231 & & & \\
\hline \multicolumn{4}{|l|}{ Education of Father } & \multirow{5}{*}{$\begin{array}{c}\text { Chi-sq } \\
(\text { yates })=16 \\
d f=2\end{array}$} & \multirow{5}{*}{$\begin{array}{l}\text { (Yates) } \\
<\mathbf{0 . 0 5}\end{array}$} \\
\hline Illiterate & $2(33 \%)$ & $4(67 \%)$ & $6(100 \%)$ & & \\
\hline *jst lit- high school & $17(53 \%)$ & $15(47 \%)$ & $32(100 \%)$ & & \\
\hline $\begin{array}{l}\text { Intermediate- } \\
\text { professional }\end{array}$ & $50(19 \%)$ & $212(81 \%)$ & $262(100 \%)$ & & \\
\hline Total & 69 & 231 & & & \\
\hline \multicolumn{4}{|l|}{$\begin{array}{l}\text { Education of } \\
\text { Mother }\end{array}$} & \multirow{5}{*}{$\begin{array}{c}\text { Chi-sq }=0.9 \\
d f=2\end{array}$} & \multirow{5}{*}{$>0.05$} \\
\hline Illiterate & $7(30 \%)$ & $16(70 \%)$ & $23(100 \%)$ & & \\
\hline *just lit-high school & $20(24 \%)$ & $63(76 \%)$ & $83(100 \%)$ & & \\
\hline \multirow[t]{2}{*}{$\begin{array}{l}\text { Intermediate- } \\
\text { professional }\end{array}$} & $42(22 \%)$ & $152(78 \%)$ & $194(100 \%)$ & & \\
\hline & 69 & 231 & & & \\
\hline \multicolumn{4}{|l|}{ Chronic illness } & \multirow{4}{*}{$\begin{array}{c}\text { Chi-sq }=9.6 \\
\text { Df }=1 \\
\text { Odds ratio }=0.28, \\
\text { CI }=0.12-0.65\end{array}$} & \multirow[b]{4}{*}{$<0.05$} \\
\hline Present & $12(48 \%)$ & $13(52 \%)$ & $25(100 \%)$ & & \\
\hline \multirow[t]{2}{*}{ Absent } & $57(21 \%)$ & $218(79 \%)$ & $275(100 \%)$ & & \\
\hline & 69 & 231 & & & \\
\hline Loss of loved one & & & & \multirow{4}{*}{$\begin{array}{c}\text { Chi-sq }=1.03 \\
\mathrm{df}=1 \\
\text { odds ratio }=0.72 \\
\mathrm{CI}=0.3-1.3\end{array}$} & \multirow{4}{*}{$>0.05$} \\
\hline Present & $18(28 \%)$ & $47(72 \%)$ & $65(100 \%)$ & & \\
\hline \multirow[t]{2}{*}{ Absent } & $51(22 \%)$ & $184(78 \%)$ & $235(100 \%)$ & & \\
\hline & 69 & 231 & & & \\
\hline \multicolumn{4}{|l|}{ Financial problem } & \multirow{4}{*}{$\begin{array}{c}\text { Chi-sq }=1.03 \\
\mathrm{df}=1 \\
\text { odds ratio }=1.4 \\
\mathrm{CI}=0.7-2.8\end{array}$} & \multirow{4}{*}{$>0.05$} \\
\hline Present & $12(18 \%)$ & $53(82 \%)$ & $65(100 \%)$ & & \\
\hline \multirow[t]{2}{*}{ Absent } & $57(24 \%)$ & $178(76 \%)$ & $235(100 \%)$ & & \\
\hline & 69 & 231 & & & \\
\hline \multicolumn{4}{|l|}{ Abused by parents } & \multirow{4}{*}{$\begin{array}{c}\text { Chi-sq } \\
\text { (yates)=5.1 } \\
\text { df }=1\end{array}$} & (Yates) \\
\hline Present & $5(63 \%)$ & $3(37 \%)$ & $8(100 \%)$ & & $<0.05$ \\
\hline Absent & $64(22 \%)$ & $228(78 \%)$ & $292(100 \%)$ & & \\
\hline & 69 & 231 & & & \\
\hline $\begin{array}{l}\text { Family history of } \\
\text { Depression }\end{array}$ & & & & $\begin{array}{c}\text { Chi-sq }=22 \\
\text { df }=1\end{array}$ & \\
\hline Present & $14(70 \%)$ & $8(40 \%)$ & $22(110 \%)$ & Odds ratio $=0.14$ & $<0.05$ \\
\hline Absent & $55(25 \%)$ & $223(80 \%)$ & $278(105 \%)$ & $\mathrm{CI}=0.05-0.3$ & \\
\hline & 69 & 231 & & & \\
\hline
\end{tabular}

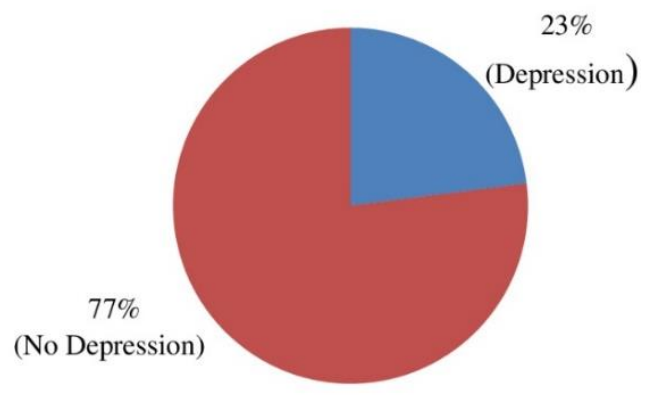




\section{Discussion}

Medical profession is one of the most Nobel professions since past and nowadays medical students are increasing every year. This study presents the report of 300 undergraduate medical students in Uttar Pradesh University of Medical sciences, Safai, Etawah, India, where this type of study was never done before.

We have used the reliable and valid depression screening tool, BDI scale. The overall depression reported by our respondent was $(23 \%)$ of which majority had mild $(9.3 \%)$ and moderate $(12 \%)$ degree of depression. The prevalence of severe and significant depression was (1.9\%) respectively. Using same BDI scale findings of the study done by Kirte RC et al $(22.1 \%)^{17}$ in a Medical college in Raichur is consistent with the results of present study and another study done by Singh et al (49.1\%) in Medical college in Northern India and by Kumar et al (71.25\%) in Mangalore, Karnataka found higher proportion of depressive symptoms among medical undergraduates. ${ }^{18,19}$ Other studies in different parts of the world also showed wide range of variation of depression among medical trainees, from $2.2 \%$ up to $85 \%$ of the students. ${ }^{5,70-26}$ Reasons are different for each study like varied demographic characteristics, different sample sizes, different scales used to assess depression and cut-offs used were also different. We found statistically significant association between prevalence of depression and family history of depression which is similar to result of a study in a medical college of Mangalore, Karnataka by Kumar et al. ${ }^{19}$ In our study we found that prevalence of depression was 1.4 times more among those with financial problem in the family than those without having it but the association was not statistically significant. This emphasizes that for medical education there should be some strategies for fees reduction during medical training so that students as well as parents do not get overburdened.

\section{Conclusion}

This study provides an idea of magnitude of depression among medical students with some of its associated factors which can be further evaluated by quantitative and qualitative methods, as this is a cross-sectional study, it is hard to identify the direction of influence and causal inferences from our study. Depression is highly prevalent among medical students and our findings point the importance of screening of this vulnerable group and taking appropriate measures to prevent complication of depression and overall development of the student. However using a valid scale to assess the depressive symptoms of the students increases the validity of the study but due to insufficient sample size results are not generalised. By providing a healthy environment, proper counselling and encouraging extracurricular activities we can prevent serious consequences to the future doctors.

\section{Acknowledgement}

We are thankful to all the medical students who participated in the study without them this study was not possible.

\section{Funding: No funding sources}

\section{Conflict of Interest: None declared}

Ethical Approval: The study was approved by the Institutional Ethics Committee of Uttar Pradesh University of Medical Sciences, Saifai, Etawah.

\section{References}

1. World Health Organization. (2018). Depression. [online] Available at:

http://www.who.int/mental_health/management/depression/en/ [Accessed 1 Jun. 2018].

2. World Health Organization. Mental and neurological disorders. Fact sheet No. 265; 2001

3. Depression [Internet]. World Health Organization. 2018 [cited 1 June 2018]. Available from: http://www.who.int/mental_health/management/depression/en/

4. Roberts LW, Warner TD, Carter D, Frank E, Ganzini L, Lyketsos C, et al. Caring for medical students as patients: Access to services and care-seeking practices of 1,027 students at nine medical schools. Collaborative research group on medical student healthcare. Acad Med 2000;75:272-277.

5. Vaidya PM, Mulgaonkar KP. Prevalence of depression, anxiety and stress in undergraduate medical students and its correlation with their academic performance. Indian $J$ of Occup Ther 2007;39:7-10.

6. Dahlin M, Joneborg N, Runeson B. Stress and depression among medical students: A cross-sectional study. Med Educ. 2005; 39: 594-604.

7. Zoccolillo M, Murphy GE, Wetzel RD. Depression among medical students. J Affect Disord 1986;11:91-96.

8. Busch MA, Maske UE, Ryl L, Schlack R, Hapke U. [Prevalence of depressive symptoms and diagnosed depression among adults in Germany: results of the German Health Interview and Examination Survey for Adults (DEGS1)]. Bundesgesundheitsblatt Gesundheitsforschung Gesundheitsschutz 2013;56:733-739.

9. Yusoff MS, Abdul Rahim AF, Yaacob MJ. Prevalence and sources of stress among Universiti Sains Malaysia Medical students. Malays J Med Sci 2010;17:30-37.

10. Shaikh BT, Kahloon A, Kazmi M, Khalid H, Nawaz K, Khan N, et al. Students, stress and coping strategies: A case of Pakistani medical school. Educ Health (Abingdon) 2004; 17:346-353

11. Saipanish R. Stress among medical students in a Thai medical school. Med Teach 2003;25:502-506.

12. Radcliffe $\mathrm{C}$, Lester $\mathrm{H}$. Perceived stress during undergraduate medical training: A qualitative study. Med Educ 2003;37:3238.

13. Firth J. Levels and sources of stress in medical students. $\mathrm{Br}$ Med J (Clin Res Ed) 1986;292:1177-1180.

14. Dyrbye LN, Matthew R, Thomas MR Shanafelt TD. Medical Student Distress: Causes, Consequences, and Proposed Solutions. Mayo Clin Proc 2005;80:1613-1622.

15. Sidana S, Kishore J, Ghosh V, Gulati D, Jiloha RC, Anand T. Prevalence of depression in students of a medical college in New Delhi: A cross-sectional study. AMJ 2012;5(5):247-250. http//dx.doi.org/10.4066/AMJ.2012.750. 
16. Beck AT, Steer RA, Garbin MG. Psychometric properties of the Beck depression inventory: twenty five years of evaluation. Clin Psychol Review 1988;8(1):77-100.

17. Kirte RC, Fahim MA. A study on assessment of depression and factors associated with it among medical students of Raichur Institute of Medical Sciences, Raichur. Int $J$ Community Med Public Health 2018;5:1623-1627.

18. Singh A, Lal A, Shekhar. Prevalence of depression Among Medical Students of a Pvt Medical College: India. Online J Health Allied Sci 2010;9(4):1-3.

19. Kumar GS, Jain A, Hegde S. Prevalence of depression and its associated factors using beck depression inventory among students of a medical college in Karnataka. Indian J Psychiatry 2012;54:223-226.

20. Clark DC, Zedlow PB. Vicissitude of depressed mood during four years of medical school. J Am Med Assoc 1988;260:25212528.

21. Levine RE, Litwins SD, Frye AW. An Evaluation of Depressed Mood in Two Classes of Medical Students. Acad Psychiatr 2006;30:235-237.

22. Chan DW. Depressive symptoms and depressed mood among Chinese medical students in Hong Kong. Compr Psychiatr. 1991;32:170-180.
23. Birmaher B, Ryan ND, Williamson DE, Brent DA. Childhood and adolescent depression: A review of the past 10 years, Part I. J Am Acad Child Adolesc Psychiatry 1996;35:1427-1439.

24. Inam SNB, Saqib A, Alam E. Prevalence of anxiety and depression among medical students of private university. $J$ Pak Med Assoc 2003;53:44-47.

25. Aniebue PN, Onyema GO. Prevalence of depressive symptoms among Nigerian medical undergraduates. Trop Doct 2008;38:157-158.

26. Marie D, Joneborg N, Runeson B. Stress and depression among medical students: A cross sectional study. Med Educ 2005;39:594-604.

How to cite this article: Singh D R, Kumar S, Bajpai P.K, Jain P.K, Mahima. Prevalence of depression among students of medical college in UPUMS, Saifai - A cross-sectional study. J Prev Med Holistic Health. 2018;4(2):68-72. 